\title{
VERSLAG VAN DIE TWEEDE INTERNASIONALE
}

\section{CALVYNKONGRES}

Dr. B. J. v.d. Walt het die kongres aan die Vrije Universiteit, Amsterdam, $25-28$ September 1978, bygewoon en doen daarvan soos volg verslag:

Eintlik was hierdie die eerste internasionale Calvynkongres. Die Calvynkongres wat vanaf $16-19$ September 1974 aan die Vrije Universiteit gehou is, was 'n Europese kongres. ${ }^{1}$ Hierdie tweede byeenkoms het nie alleen meer navorsers getrek nie (ongeveer 80 teenoor die 40 Calvynkenners by die eerste byeenkoms), maar die kongresgangers het ook veel meer lande (16) verteenwoordig selfs van so vêr as die VSA, Kanada, Japan, Korea en Suid-Afrika. Ook lande agter die ystergordyn soos die Deutsche Demokratische Republik, Hongarye en Roemenië was goed verteenwoordig.

Opmerklik was ook dat dit nie alleen Calviniste was wat in Calvynnavorsing belangstel nie. Afgesien van die feit dat baie kongresgangers nie tot kerke behoort wat ons as Calvinisties sou bestempel nie, was die Lutherse ook verteenwoordig (in die persoon van prof. dr. M. Seils, verteenwoordiger van die Uitvoerende Komitee van die Internasionale Luthernavorsingskongres) sowel as 'n hele aantal Roomse-Katolieke Calvynnavorsers.

Dit wil voorkom asof Rooms-Katolieke geleerdes op die oomblik meer geinteresseerd is in Calvyn as enige ander van die sestiendeeeuse reformatore. (Ook die eerste kongres is deur heelwat RoomsKatolieke bygewoon.) Calvynstudie het 'n ekumeniese aangeleentheid geword!

'n Mens sou maklik kan stry oor die vraag wie van die baie reformatore uit die sestiende eeu die belangrikste hervormer was. Gelukkig het dit nie gebeur nie - hoewel prof. F. Büsser van Zürich darem nie kon nalaat om daarop te wys dat Bullinger net so ' $n$ belangrike rol as Calvyn gespeel het nie! Op humoristiese wyse het prof. Schenkeveld (rector magnificus van die Vrije Universiteit) by sy verwelkoming daarop gewys dat hy in sy jeug geleer is dat alle -ismes behalwe die Calvinisme uit die bose is. In sy jeug was die kritiek op Calvyn dus min en, indien dit wel voorgekom het, goed geneutraliseer met groot waardering! Die bedoeling van die kongres was beslis nie om Calvyn óf te vergruis of te kanoniseer nie. Tereg het prof. Locher die kongresgangers in 'n slotwoord aangespoor om Calvyn ernstig te bestudeer, maar nog ernstiger die Woord van God.

\section{Tema en doelstellings}

Die tema was Calvinus Ecclesiae Doctor. (Calvyn, leermeester van die kerk). Dit het dus hoofsaaklik weer om Calvyn se teologie gegaan (vgl. tema van eerste kongres: Calvinus Theologus) hoewel hierdie keer tog ook oor die invloed van sy teologie. Ook die toepassing van moderne liguistieke metodes (vgl. referate Vincent en Pin) het 'n plek op die program gekry. 
In sy openingsrede het die sekretaris, prof. W. H. Neuser, die volgende drie doelstellings vir die byeenkoms gestel:

$+\quad$ Om die belangrikste gebiede van huidige Calvynnavorsing te identifiseer en vas te stel waar daar nog leemtes bestaan.

+ Om mekaar op hoogte te bring met nasionale of streekbyeenkomste, belangrike navorsingsprojekte, publikasies ens. Dit is baie belangrik dat in die internasionale Calvynnavorsing sulke informasie deurgegee word om isolasie te voorkom en koördinasie te bevorder.

+ Om op persoonlike vlak en ook meer formele vlak (referate en diskussies) idees uit te ruil en mekaar te stimuleer.

\section{Sprekers en referate}

Die titels van die referate word in Engels gegee met indien dit nie in Engels gelewer is nie, die titel in die taal waarin dit oorspronklik gelewer is tussen hakies.

\section{Maandag 25 September}

+ Prof. dr. W. H. Neuser (Münster, Duitsland): Openingsrede.

+ Dr. W. Balke (Den Ham, Nederland): „The Word of God and experiatia according to Calvin".

Dinsdag 26 September

+ Prof. dr. H. Schützeichel (Trier, Duitsland): „Calvin and the discussions of penance at the 1551 sessions of the Council of Trente" (Calvyn in den Trienter Beratungen über die Busse im Jahre 1551).

+ Prof. dr. R. Stauffer (Parys): "Some infamiliar aspects of the theology of the first head of doctrine in the preaching of Calvin" (,Quelques aspects insolites de la theology du premier article dans la predication de Calvin").

+ Prof. dr. J. B. Torrance (Aberdeen, Skotland): „The vicarious humanity and priesthood of Christ in the theology of John Calvin".

Woensdag 27 September

+ Dr. T. H. L. Parker (Durham, England): „Commentary on Romans: Calvin the exegete - change and development".

\section{Donderdag 28 September}

+ Prof. dr. F. L. Battles (Grand Rapids, VSA): „Calculus Fidei. Some ruminations on the structure of Calvin's theology".

+ Prof. G. Vincent (Strasbourg, Frankryk): „Calvin's theology of the sacrament in the light of the linguistic theory of performatives” (,La Theologie Calvinienne du sacrament a la lumière de la linguistique").

+ Dr. J. Pin (Toulouse, Frankryk): „A textual analysis of theological discourse in the Cathechism (1542) of John Calvin” ( „Analyse textuelle du discours Theologique du Cathechisme (1542) de Jean Calvin"). 
+ Prof. dr. M. Bucsay (Budapest, Hongarye): "The presence of Calvin in Hungary during the Reformation era, 1512-1608" (,Calvins Präsenz in Ungarn").

+ Prof. dr. A. Fatio (Genève, Switzerland): „Calvin's presence in Reformed Ortodoxy” („La presence de Calvin dans l' Orthodoxie Reformee").

\section{Gehalte van referate en diskussies}

Daar was geen taalprobleme wat die volg van die verrigtinge belemmer het nie. Die referate is wel in die taal van die spreker (of een van die drie amptelike tale wat hy die beste kon beheers) gelewer, maar al die referate was in drie tale (Engels, Frans en Duits) beskikbaar. Die sekretaris het in hierdie opsig ' $n$ besondere diens verrig as in aanmerking geneem word hoeveel moeite en geld vertaling kos. Die diskussie kon ook in genoemde drie tale gevoer word - hoewel die vertaling in Engels (dikwels a.g.v. die feit dat sprekers te vinnig gepraat het) soms maar afgeskeep is.

Hoewel elkeen sy eie besondere belangstelling het en uiteraard dus meer waardering vir sekere referate sou hê was al die stukke van hoogstaande gehalte. Ook die diskussie was verhelderend. Dit het dikwels bestaan uit bydraes wat meer gegewens oor 'n bepaalde faset gebied het. Dit is onmoontlik om hier aan te toon in watter opsigte elke lesing tot 'n persoonlike verryking van 'n mens se kennis bygedra het. (Persoonlik het dit my o.a. in staat gestel om my voorlopige verslag n.a.v. my besoek aan verskillende institute vir reformasienavorsing in Europa nog vollediger te maak en finaal te kontroleer. Dit verskyn binnekort in Koers onder die titel „Ad Fontes. Internasional research in the Reformation of the 16th Century").

Dit is alleen jammer dat referate nie voor die konferensie beskikbaar gestel is nie en selfs ook nie op die konferensie uitgedeel is voordat die referente aan die woord gekom het nie. Daarom moes al die referate in hul geheel eers weer voorgedra word. Dit het meestal 'n uur na $1 \frac{1}{2}$ uur in beslag geneem: Indien dit nie nodig was nie, sou veel meer tyd vir bespreking beskikbaar gewees het.

Al die referate sal (deur die sekretaris) in die oorspronklike taal waarin dit gelewer is gepubliseer word in 'n bundel met die titel Calvinus Ecclesiae Doctor.

\section{Besigheidsvergadering}

Behalwe ' $n$ verslag van die werksaamhede van die reëlingskomitee die afgelope vier jaar asook die stand van die finansies, het die volgende aan die orde gekom:

+ Die moontlikheid van 'n eie blad vir Calvynnavorsing.

+ Streekkonferensies tussen kongresse is aangemoedig. In die verband is vermeld dat daar reeds in 1977 in S.A. 'n Calvynkongres gehou is (10 - 11 Augustus 1977 te Pretoria) en dat 'n volgende beplan word.

Die Suid-Afrikaners op die konferensie (Proff. A. D. Pont, L. F. Schulze, dr. A. J. van Rooy en ekself) het die saak met prof Neuser bespreek en hy het alle moontlike hulp wat hy sou kon 
bied, belowe. Die moontlikheid bestaan dat die RGN soiets sou kon help organiseer en o.a. Dept. Inligting nader om die oorsese sprekers uit te nooi en hul reiskostes te betaal. Daar word aan 1981 gedink en voorlopig is afgespreek om in November in Pretoria die saak verder te bespreek. ('n Tema soos „Calvyn se betekenis vir Suid-Afrika vandag" word oorweeg).

\section{+ Bibliografiese navorsing}

Dr. P. de Klerk (Bibliotekaris van Calvin Theological Seminary, Grand Rapids) het besonderhede verstrek oor die Calvynbibliografie wat sedert 1971 jaarliks in Calvin Theological Journal verskyn. Die bedoeling is om binnekort 'n uitgawe die lig te laat sien waarin al sewe afsonderlike bibliografieë saamgevat word. Hy versamel ook gegewens sedert 1960 (W. Niesel se bibliografie het in 1959 opgehou) en die plan is om teen 1988 (dws 30 jaar na Niesel se bibliografie) 'n volledige bibliografie die lig te laat sien.

Prof. R. Peter (Strasbourg) het ook enkele mededelings oor sy bibliografiese navorsing (veral ou tekste) gedoen.

Ook oor die werk van die IBC is gerapporteer en van Kempff se $A$ bibliography of Calviniana 1959-1974 is 'n stuk of ses eksemplare van die hand gesit.

+ „Supplementa Calviniana” (Bevattende Calvyn se preke). Dit blyk dat die rede vir die vertraging by die verskyning hiervan hoofsaaklik finansieël is. Verskeie manuskripte is persklaar maar die geld ontbreek. Hopelik verskyn in 1979 'n volgende deel.

\section{+ Calvynnavorsing in verskillende lande}

VSA: Tweede Calvin Colloquium, 16, 17 November 1978 te Calvyn College.

Japan: 'n Kort verslag oor wat van Calvyn reeds in Japanees vertaal is.

Korea: 'n Uitgebreide verslag van prof. J. S. Rhee (Seoul) oor die geskiedenis van die kerk in Japan en die belangstelling in Calvyn met 'n volledige lys van werke van en oor Calvyn en die Calvinisme in Koreaans beskikbaar.

Zürich: Bekendstelling deur prof. F. Büsser van 'n nuwe projek wat Bullinger se geskrifte op microfice beskikbaar sal stel.

\section{$+\quad$ Volgende kongres}

Met toevoeging van E. D. Dowey (Princeton) sal die bystaande reëlingskomitee, nl. M. Bucsay (Boedapest), G. W. Locher (Bern), T. H. L. Parker (Durham), R. Peter (Strasbourg), W. van 't Spijker (Apeldoorn) en W. H. Neuser, sekretaris (Münster) die volgende kongres beplan wat DV in 1982 in Genève sal plaasvind. (Daar word reeds planne beraam om vier jaar daarna, in 1986, in Hongarye te vergader).

Verskillende temas is deur die kongresgangers ter oorweging deur die reëlingskomitee genoem. Die moontlikheid sal ook oorweeg word om tydens die volgende kongres nie net plenêr te ver- 
gader nie, maar in sessies volgens verskillende belangstellingsrigtings. Daar sal ook gepoog word om referate voor die kongres beskikbaar te stel.

Adres vir navrae:

Prof. W. H. Neuser (Sekretaris),

Lehmbrock 17,

4401 Ostbevern bei Münster,

WES-DUITSLAND.

\section{Bedanking}

My hartlike dank aan die RGN wat dit vir my finansieël moontlik gemaak het om die kongres te kon bywoon asook aan die IBC wat daartoe verlof gegee het. Dit was 'n besondere geleentheid om Calvynspesialiste van oor die hele wêreld aan die werk te sien. Ek verseker $u$ dat die verryking wat dit gebied het 'n neerslag sal vind in my verantwoordelikheid t.o.v. die IBC/RGN-projek ,Die inslag van die Calvinisme in Suid-Afrika".

1 Referate by die geleentheid gelewer, is gepubliseer deur W. H. Neuser (red). onder die titel: Calvinus Theologus Neukirchen, Neukorchener Verlag, 1876 ( 157 bladsye). 